\title{
Parenting styles as a predictor of social competence in medical profession students in dealing with patients in makassar
}

\author{
Andi Mardyah Mursal \\ Department of Psychology, Faculty of \\ Medicine \\ Hasanuddin University \\ Makassar, Indonesia \\ andimardyah@gmail.com
}

\author{
Grestin Sandy R \\ Department of Psychology, Faculty of \\ Medicine \\ Hasanuddin University \\ Makassar, Indonesia
}

\author{
Nirwana Permatasari \\ Department of Psychology, Faculty of \\ Medicine \\ Hasanuddin University \\ Makassar, Indonesia
}

\begin{abstract}
This research is a quantitative research that aims to know the description of parenting style as predictor of social competence of medical profession students in facing patients in Makassar City. Subjects in this study amounted to 96 students of medical professions who came from three Universities in Makassar. The subjects were chosen by using purposive sampling technique. This study uses two scales, namely the scale of parenting style and social competence scale and analyzed by using simple regression analysis technique.

The results showed that parenting style is able to predict the social competence of medical profession students as much as $20.8 \%$. Authoritative parenting is able to predict 19.7 percent so it can be said to predict the social competence significantly. Authoritarian parenting is able to predict as much as $8.1 \%$ and is deemed to be able to significantly predict social competence. Neglectful parenting is able to predict social competence by $0.2 \%$ so it is said to not be significant in predicting social competence. Indulgent parenting is able to predict social competence by $0.1 \%$ so it is said to not be significant in predicting social competence. Based on these results it is concluded that the types of parenting style that is able to predict the social competence of medical profession students are Authoritative parenting and Authoritarian parenting.
\end{abstract}

Keywords- Parenting Style; Social Competence; Medical Profession Student.

\section{INTRODUCTION}

Early adulthood is the age at which individuals begin and develop careers. Santrock [1] explains that individuals who want to start a career will continue their education to a higher level such as university and will choose majors that have higher career success opportunities such as education and health services, professional services, and business. Akmal [2] states that 75,224 prospective students in Indonesia have a desire to study in the medical education department, specifically doctoral. Department of medical education is a department that aims to produce professional doctors through a standardized process according to the needs of public health services. The Indonesian Ministry of Health in 2015 explained that the ratio between physicians and residents is 1: 4000. Based on this data, the number of doctors is still very limited, while the number of people who need health services is quite a lot. Due to the limited number of doctors versus the number of patients, doctors need to have the ability and skills to provide satisfactory service to patients.

The provision of health services provided by hospitals is stipulated in Law No.44 of 2009 Article 32 paragraph 1 (c) stating that every patient is entitled to humane, fair, honest, and non-discriminatory services. However, in some studies it appears that hospitals provide poor service by neglecting and sometimes even rejecting patients. One of the parties involved in the provision of health services is a student of the medical profession. Research by Kopacz, Grossman \& Klamen [3] and Chew \& Cheong [4] shows that medical professionals lack the ability to demonstrate positive attitudes toward patients; this is one of the social competencies that should be held by medical profession students. Tychmanowicz and Kuspit [5] explained that medical profession students should have high social competence to be able to provide health services to patients. The level of social competence possessed by students of the medical profession is influenced by several factors, namely temperament, communication skills, and family. Semrud [6] explains that parents' relationship with children is influential in the development of children's social competence. Leidy, Guerra, and Toro [7] explained that there is a significant relationship between parenting style and the development of individual social competence. This is because individuals learn about social skills through modeling and reinforcement in childhood.

Students of the medical profession should have good social competence to be able to deal with patients. When students of the medical profession have good social competence, they will be able to communicate effectively, realize, and understand the emotions felt by the patients they will face. One factor that can be influential in the development of individual social competence is the parenting style that individuals get from parents. The results of the research that has been described above found that the parenting style is related to the social competence possessed by medical profession students. Thus, the aim of this research is to find out to what extent parenting style predicts the social competence of clinical course students in facing patients in Makassar City. 


\section{LITERATURE REVIEW}

\section{A. Parenting Styles}

The parenting styles referred to in this study is the way parents nurture and raise students of the medical profession that will affect the students' behavior in dealing with patients. There are four types of parenting styles: Authoritative parenting, Authoritarian parenting, Neglectful parenting and Indulgent parenting. Authoritative parenting is where parents encourage medical profession students to be independent but still provide limits and control over their actions. Authoritarian parenting is a parenting pattern in which parents are limiting and punishing. Neglected parenting is a parenting pattern in which parents are not involved in the life of medical profession students. Indulgent parenting is a parenting pattern where parents are too involved in the development of medical profession students and do not provide demands or controls.

\section{B. Social Competence}

Social competence referred to in this study is the ability possessed by medical profession students in showing behavior toward patients. The aspects of social competence are assertion, cooperation, empathy, responsibility and self-control. Assertion is when the student has the initiative to communicate with patients. Cooperation is when a student of the medical profession helping patients and sharing knowledge with fellow professional friends. Empathy is when a student of the medical profession shows concern and respect for the patient. Responsibility when is a student of the medical profession appreciates the work of others and appreciating the patient. Self-control is when a student of the medical profession demonstrates appropriate behavior regarding the patient's condition.

\section{RESEARCH METHODS}

\section{A. Participants}

The population in this study is medical profession students in Makassar. The sample in this study is part of the number and characteristics possessed by the population. This research is used purposive sampling as sampling technique that according to the desired criterion determined by researcher. The criteria determined by the researcher are as follows:

- Students in early adulthood, aged 20 - 25 years

- Medical profession student in Makassar City

- Coassisting at Hospitals in Makassar City.

\section{B. Procedures}

Data was taken by visiting several hospitals located in Makassar. Data collection is done by visiting polyclinics in which there are students of the medical profession and then asking help to the medical students to share the scale to the friends of other medical profession students.

\section{Measures}

The research instrument used in this research is the scale of parenting style and the scale of social competence. The scale of parenting style and the scale of social competence are prepared by the author. Both scales went through the processes of face and content validity with expert judgment. After going through these processes, they were then tested for their validity and reliability by using the total item correlation through SPSS 22 for windows and CFA through LISREL 8.70.

Through total correlation analysis test, it was found that there were items in the Parenting style scale that are invalid. Invalid items were then discarded, and items that are valid through the correlation of total item was then validity tested using Confirmatory Factor Analysis (CFA) through LISREL 8.70. One aspect is known to meet the criteria of a fit model if p-value $>0.05$ and RMSEA $<0.05$. In addition, items can be said to be valid if loading factor is positive and t-value $>1.96$. From the validity test through CFA it is found that there are two items that do not meet the predetermined standard, so that the items are again discarded. Items are then re-tested for their reliability through Explanatory Factor Analysis (EFA) using Cronbach's Alpha via IBM SPSS 22 for windows. The value of Cronbach's Alpha on this scale is 0.421 .

The scale of social competence through total correlation analysis test showed that there were some invalid items. Invalid items were then discarded, and the items that have been proven to be valid through the correlation of total item were then tested for its validity using Confirmatory Factor Analysis (CFA) through LISREL 8.70. One aspect is known to meet the criteria of a fit model if p-value $>0.05$ and RMSEA $<0.05$. In addition, items can be said to be valid if loading factor is positive and $t-$ value $>1.96$. From the validity test through CFA it is found that there are two items that do not meet the predetermined standard, so that the items are discarded. Items are then retested for its reliability through Explanatory Factor Analysis (EFA) using Cronbach's Alpha via IBM SPSS 22 for windows. The value of Cronbach's Alpha on this scale is 0.904.

After going through the reliability and validity processes of both scales, researchers went down the field to take research data. After obtaining the necessary data, the researchers input the data first and then test the validity and reliability of 100 data that has been obtained. The validity test used for the parenting style scale and social competence scale is the content and construct validity (CFA), and the reliability test used is Cronbach's Alpha. The data obtained to be the subject of research is 96 .

\section{RESULTS}

FIGURE 1. PARENTING STYLE DESCRIPTION WHICH IS INTERNALIZED BY MEDICAL PROFESSION STUDENTS

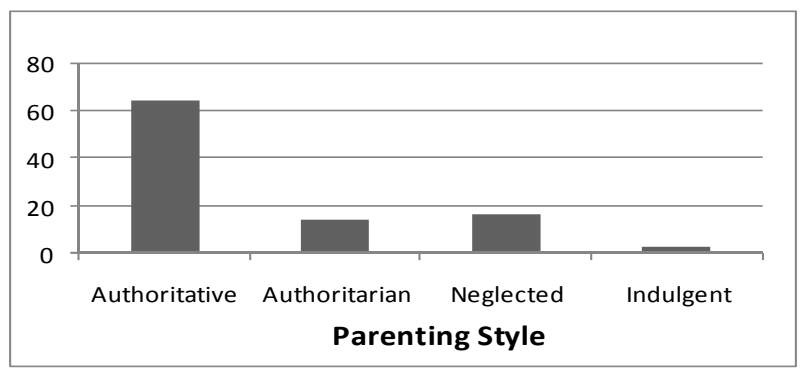


Based on the picture above, it can be seen that the medical profession students who internalized authoritative parenting style are 64 people $(66.7 \%)$, medical profession students who internalized authoritarian parenting style were as many as 14 people $(14.5 \%)$, medical profession students who internalized neglectful parenting style were as many as 16 people (16.7\%), and medical profession students who internalized indulgent parenting style were as much as 2 people $(2.1 \%)$.

TABLE I

DETERMINATION OF SIMPLE REGRESSION ANALYSIS COEFFICIENT TABLE

\begin{tabular}{crrrr}
\hline Model & R & R Square & Adjusted R Square & $\begin{array}{c}\text { Std. Error of the } \\
\text { Estimate }\end{array}$ \\
\hline 1 & $.465^{\mathrm{a}}$ & .217 & .208 & 14.03096 \\
\hline
\end{tabular}

Based on table I above, it can be seen that the value of determination coefficient (adjusted R Square) obtained is 0.208 which indicates that parenting style authoritative, authoritarian, neglectful, and indulgent which is shared by medical profession students together have an influence on social compensation equal to $20.8 \%$.

\section{TABLE II}

TABLE F SIMPLE REGRESSION ANALYSIS

\begin{tabular}{ccccccc}
\hline & Model & Sum of Squares & df & $\begin{array}{c}\text { Mean } \\
\text { Square }\end{array}$ & F & Sig \\
\hline \multirow{4}{*}{1} & Regression & 5119.075 & 1 & 5119.075 & 26.003 & $000^{\mathrm{b}}$ \\
& $\begin{array}{c}\text { Residual } \\
\text { Total }\end{array}$ & 18505.581 & 94 & 196.868 & & \\
\hline
\end{tabular}

Based on table $\mathrm{F}$ above can be seen that the significance value obtained is 0.000 , where 0.000 is smaller than 0.05 $(0.000<0.05)$. Thus it can be concluded that authoritative, authoritarian, neglectful, and indulgent parenting styles significantly predict the social competence possessed by medical profession students in dealing with patients. In addition, the results of the $F$ test above also show that a simple linear regression equation model is feasible to use.

TABLE III

TABLE R SQUARE CHANGE REGRESSION ANALYSIS

\begin{tabular}{|c|c|c|c|c|c|c|c|}
\hline \multirow[b]{2}{*}{ Model } & \multirow[b]{2}{*}{$\mathbf{R}$} & \multirow[b]{2}{*}{$\mathbf{R}^{2}$} & \multirow[b]{2}{*}{$\begin{array}{l}\text { Adjus } \\
\text { ted } \mathbf{R}^{2}\end{array}$} & \multirow[b]{2}{*}{$\begin{array}{c}\text { Std. } \\
\text { Error of } \\
\text { the } \\
\text { Estimate }\end{array}$} & \multicolumn{3}{|c|}{ Change Statistics } \\
\hline & & & & & $\begin{array}{c}\mathbf{R}^{2} \\
\text { Chan } \\
\text { ge }\end{array}$ & $\begin{array}{c}\text { F } \\
\text { Cha } \\
\text { nge }\end{array}$ & $\begin{array}{l}\text { Sig. } \\
\text { F } \\
\text { Cha } \\
\text { nge }\end{array}$ \\
\hline 1 & 0.137 & 0.197 & 0.008 & 10.70459 & 0.197 & 1.788 & 0.018 \\
\hline 2 & 0.165 & 0.027 & 0.006 & 10.72033 & 0.081 & 0.812 & 0.037 \\
\hline 3 & 0.165 & 0.027 & 0.004 & 10.80500 & 0.002 & 0.006 & 0.937 \\
\hline 4 & 0.015 & 0.000 & 0.010 & 10.85139 & 0.001 & 0.022 & 0.956 \\
\hline
\end{tabular}

Based on table III, we can see the significance of each type of awareness of parenting style in column Sig.F Change $(<0.05)$ and how much the types of parenting style contribute in determining the social competence of medical profession students in dealing with patients. In model 1, the Authoritative
Parenting is able to predict $19.7 \%$ so it can be said to be able to predict significantly social competence (sig.F Change 0.018 $<0.05$ ). In model 2 , the Authoritarian parenting is able to predict as much as $8.1 \%$ and it is said to be able to predict significantly social competence (Sig.F change $0.037<0.05$ ). In model 3, Neglectful parenting is able to predict the social competence of $0.2 \%$ but Sig.F Change is above 0.05 (0.937> $0.05)$, so it is not significant in predicting social competence. In model 4, Indulgent parenting is able to predict social competence of $0.1 \%$ but Sig.F Change value is above 0.05 (0.956>0.05), so it is said to not be significant in predicting social competence.

\section{DISCUSSIONS}

There are two problem formulations in this research, which are knowing the description of parenting style of medical profession students in Makassar City and to find out how much parenting style acts as a predictor to social competence of medical profession students in facing patients in Makassar City.

Regarding the first problem, it was found that medical profession students who internalized authoritative parenting style were as many as 64 people $(66.7 \%)$, medical profession students who internalized authoritarian parenting style were as many as 14 people (14.5\%), medical profession students who internalized neglectful parenting style were as many as 16 people $(16.7 \%)$, and medical profession students who internalized indulgent parenting style as much as 2 people $(2.1 \%)$. These results indicate that the majority of medical professionals $(66.7 \%)$ receive authoritative parenting style. Based on these results it appears that medical professional students get different parenting styles. The study also found out how medical student students describe relationships with parents. The description is as follows: very good with as many as 26 people $(27.1 \%)$, parents allow children to be responsible with as many as 4 people $(4.2 \%)$, unfamiliar relationships as many as 8 people $(8.3 \%)$, teachers as many as 2 people $(2.1$ $\%)$, discussion friends as many as 16 people (16.7\%), a figure I can depend on as many as 4 people $(4.1 \%)$, very close as many as 19 people $(19.8 \%)$, everything as many as 7 people $(7.2 \%)$, harmonic $(8 \%)(8.3 \%)$, perfect as much as 1 person $(1.1 \%)$ and father and mother differ in giving treatment as much as 1 person $(1.1 \%)$.

Based on the result of the internalization of medical profession students on the relationship they have with the parents associated with the type of parenting style it is found that the children are very well connected with their parents, the parents allow the children to be responsible, very close, everything, harmonious, perfect, and discussion friends are the characteristics of Authoritative parenting. Unfamiliar relationships and teachers are characteristic of the Authoritarian parenting. A reliable figure is a characteristic of Indulgent parenting. The medical profession students who have a different relationship between the father and the mother stated that the father is a busy person so they are not too close while the mother is always caring and paying attention, so the 
typical medical profession student feels very close to the mother. The difference in the role between father and mother is influenced by several things. Hurlock [8] explains that mothers tend to better understand children and the needs of children compared to fathers, whereas fathers tend to use authoritarian parenting patterns compared to mothers.

The second problem is to know the description of parenting style as a predictor of the social competence of medical profession students in facing patients in Makassar City. This can be seen from the value of determination coefficient (adjusted R Square) obtained is 0.208 which indicates that the parenting style internalized by students of the medical profession have an influence on social competence by $20.8 \%$. Based on the significant value of $F$ that has a value less than $0.05(0.000<0.05)$ it can be concluded that the parenting style significantly predicts the social competence possessed by students of the medical profession in dealing with patients. From the results of the study it was also found that the authoritative parenting is able to predict by $19.7 \%$ so it can be said that the authoritative parenting is able to predict the competence significantly (sig.F change 0.018 $<0.05)$. Authoritarian parenting is able to predict by $8.1 \%$, so it showed that Authoritarian parenting is able to predict competence significantly (Sig.F change 0.037 <0.05). Neglectful parenting is able to predict social competence by $0.2 \%$ but, Sig.F Change value is above 0.05 (0.937> 0.05), so it is said that Neglectful parenting is not significant in predicting social competence. Indulgent parenting is able to predict social competence $0.1 \%$ but Sig.F Change value is above $0.05(0.956>0.05)$, so it is not significant in predicting social competence. Based on these results, it can be seen that there are only two types of parenting style that can predict the social competence of medical profession students in dealing with the patients, which are Authoritative parenting and Authoritarian parenting.

The results of this study are in line with the results of research by Mensah and Kuranchie [9] which states that the parenting style that gives a significant influence on social competence is the Authoritative parenting and Authoritarian parenting. Children who have authoritative parents are found to have good social competence while children with authoritarian parents are found to have poor social competence. Other research conducted by Ren and Edwards [10] also shows that parenting style is a factor that affects parents' expectations of individual social competence. Children cared for by Authoritative parenting tend to have good social competence compared to children cared for by Authoritarian parenting. Altay and Güre [11] also found that parenting style significantly affects individual social competence. Children who have authoritative parents tend to have a negative relationship with peers compared with children with indulgent parents. Based on the results of research conducted and the results of research by other researchers found that parenting style can significantly be a predictor of social competence in children.
Based on the research that has been done the researcher found that the limits of research in this research is medical profession students are spread in several hospitals in Makassar City, so it is not possible for researchers to visit each hospital. In addition, additional research samples are still needed to dig deeper about parenting style and social competence. Therefore, in the future the author suggests to broaden the sample research, taking the data more thoroughly and deeply, and using the interview method to dig deeper about parenting style and social competence.

\section{CONCLUSION}

This study set out to investigate to what extent parenting style predicts social competence of medical profession students in facing patients in Makassar City. It is found that parenting style is significantly contribute to social competence in clinical course student. Moreover, it is found that only authoritative parenting and authoritarian parenting are sign5ificant predictors to social competence that contribute to $20.8 \%$ and $19.7 \%$ respectively. The findings of this study is supporting prior research which state that parenting style play significant role in developing children social competence [9][10][11].

The results showed that parenting style is able to predict the social competence of medical profession students as much as $20.8 \%$. Authoritative parenting is able to predict $19.7 \%$ so it can be said to predict the social competence significantly. Authoritarian parenting is able to predict as much as $8.1 \%$ and is deemed to be able to significantly predict social competence. Neglectful parenting is able to predict social competence by $0.2 \%$ so it is said to not be significant in predicting social competence. Indulgent parenting is able to predict social competence by $0.1 \%$ so it is said to not be significant in predicting social competence. Based on these results it is concluded that the types of parenting style that is able to predict the social competence of medical profession students are Authoritative parenting and Authoritarian parenting.

\section{REFERENCES}

[1] J.W. Santrock. Live Span Development 13 ${ }^{\text {ed }}$. Jakarta: Penerbit Salemba Humanika, 2012.

[2] F.K. Akmal. (2017). "Pendidikan Kedokeran Paling Banyak diminati di SBMPTN $2017 \quad$ Unhas." Internet: http://edukasi.rakyatku.com/read/52642/2017/06/13/pendidikankedokteran-paling-banyak-diminati-di-sbmptn-2017-unhas, Jun. 13, 2017 [Aug. 6, 2017].

[3] Kopacz, Grossman, \& Klamen. "Medical Students and AIDS: Knowledge, attitudes, and implications for education." Health Education Research, vol. 14, pp. $1-6,1999$.

[4] B.H. Chew., and A.T. Cheong. "Assessing HIV/AIDS Knowledge and Stigmatizing Attitudes among Medical Students in University Putra Malaysia." Article of Medicine and Health Sciences, vol. 68, pp. 24-29, 2013.

[5] A. Tychmanowicz., and M. Kuśpit. "Social Competence of Health service worker: Pilot Study." Program Health Science The Maria CurieSklodowska University. vol. 2, pp. 107 - 112, 2012.

[6] M.C. Semrud. Social Competence in Children. Springer: USA: Springer, 2007.

[7] M.S. Leidy., N.G. Guerra, N.G., and R.I. Toro. "Positive Parenting, Family Cohesion, and Child Social Competence Among Immigrant 
Latino Families.” Journal of Family Psychology, vol. 24, pp. 252 - 260, 2010 .

[8] E.B. Hurlock. Psikologi Perkembangan: Suatu Pendekatan Sepanjang Rentang Kehidupan. Jakarta: Erlangga, 1988.

[9] M.K. Mensah., and Kuranchie. "Influence of Parenting on the Social Development of Children." Academic Journal of Interdisciplinary Studies, vol. 2, pp. 123 - 130, 2013.
[10] L. Ren., and C.P. Edwards. "Pathways of Influence: Chinese parents' expectations, parenting styles, and child social competence." Early Child Development and care, vol. 185, pp. 614-630, 2015.

[11] F.B. Altay., and A. Güre. "Relationship among the Parenting Styles and the Social Competence and Prosocial Behaviors of the Children Who are Attending to State and Private Preschools." Journal of Educational Sciences, vol. 12, pp. 2712 - 2718, 2012 